\title{
Critical ranges for leaf nitrogen and potassium levels in coffee fertigated at the production phase ${ }^{1}$
}

\author{
Faixas críticas de teores foliares de nitrogênio e potássio para o cafeeiro fertirrigado \\ em fase de produção
}

\author{
Gleice Aparecida de Assis ${ }^{2 *}$, Rubens José Guimarães ${ }^{3}$, Alberto Colombo ${ }^{4}$, Myriane Stella Scalco ${ }^{4}$ e Anderson \\ William Dominghetti ${ }^{3}$
}

\begin{abstract}
With the aim of establishing critical ranges for the leaf nitrogen (N) and potassium (K) levels in fertigated coffee crops under production, an experiment was carried out in the experimental area of the Sector for Coffee Cultivation of the Department of Agriculture at the Federal University of Lavras, in Brazil. Treatments consisted of five levels of fertilizer applied through fertigation: $30 \%, 80 \%, 130 \%, 180 \%$ and $230 \%$ of the recommended amounts of $\mathrm{N}$ and $\mathrm{K}$ for rainfed coffee grown in Minas Gerais. A randomised block design with four replications was used. Critical ranges for nutrient concentrations in the leaves were established from the results of growth characteristics (plant height and stem diameter), leaf analyses and productivity. The results obtained were: a) nitrogen $\left(\mathrm{g} \mathrm{kg}^{-1}\right): 32.39$ to 32.40 for January/February; 33.60 to 33.61 for March/April; 27.39 to 27.42 for May/June; 24.23 to 24.24 for July/August; 26.06 to 26.09 for September/October and 26.50 to 26.51 for November/December; b ) potassium ( $\left.\mathrm{g} \mathrm{kg}^{-1}\right): 20.08$ to 20.14 for January/February; 17.89 to 17.91 for March/April; 15.93 to 15.96 for May/June; 15.29 to 15.35 for July/August; 16.61 to 16.64 for September/October and 20.58 to 20.64 for November/December.
\end{abstract}

Key words: Coffea arabica L.. Irrigated coffee. Critical level. Foliar diagnosis.

RESUMO - Com o objetivo de estabelecer as faixas críticas de teores foliares de nitrogênio (N) e potássio (K) para lavouras cafeeiras em produção fertirrigada, foi conduzido um experimento no campo experimental do Setor de Cafeicultura do Departamento de Agricultura da Universidade Federal de Lavras. Os tratamentos constaram de cinco níveis de adubação aplicados via fertirrigação: $30 \%, 80 \%, 130 \%, 180 \%$ e $230 \%$ da recomendação de $\mathrm{N}$ e $\mathrm{K}$ para cafeeiros cultivados em sequeiro em Minas Gerais. Foi utilizado o delineamento em blocos casualizados com quatro repetições. Com os resultados das características de crescimento (altura de planta e diâmetro de caule), análises foliares e produtividade foram estabelecidas faixas críticas das concentrações de nutrientes nas folhas. Os resultados obtidos foram: a) nitrogênio $\left(\mathrm{g} \mathrm{kg}^{-1}\right): 32,39$ a 32,40 em janeiro/fevereiro; 33,60 a 33,61 em março/abril; 27,39 a 27,42 em maio/ junho; 24,23 a 24,24 em julho/agosto; 26,06 a 26,09 em setembro/outubro e 26,50 a 26,51 em novembro/dezembro; b) potássio $\left(\mathrm{g} \mathrm{kg}^{-1}\right): 20,08$ a 20,14 em janeiro/fevereiro; 17,89 a 17,91 em março/abril; 15,93 a 15,96 em maio/junho; 15,29 a 15,35 em julho/agosto; 16,61 a 16,64 em setembro/outubro e 20,58 a 20,64 em novembro/dezembro.

Palavras-chave: Coffea arabica L.. Cafeicultura irrigada. Nível crítico. Diagnose foliar.

\footnotetext{
*Autor para correspondência

${ }^{1}$ Recebido para publicação em 19/04/2013; aprovado em 22/10/2014

Parte de tese do primeiro autor apresentada na.Universidade Federal de Lavras; pesquisa financiada pelo Consórcio Pesquisa Café

${ }^{2}$ Instituto de Ciências Agrárias, Universidade Federal de Uberlândia, Campus Avançado de Monte Carmelo, Monte Carmelo- MG, Brasil, 38.500-000, gleiceufu@gmail.com

${ }^{3}$ Departamento de Agricultura, Universidade Federal de Lavras, Lavras- MG, Brasil, 37.200-000, rubensjg@dag.ufla.br, andersonwd10@yahoo.com.br ${ }^{4}$ Departamento de Engenharia, Núcleo de Engenharia de Água e Solo, Universidade Federal de Lavras, Lavras-MG, Brasil, 37.200-000, acolombo@dag.ufla.br,msscalco@deg.ufla.br
} 


\section{INTRODUCTION}

In Brazil there are about 251,000 hectares of irrigated coffee, where average production potential yields 10 million bags per year. Of this area, 28.6\%, corresponding to 71,700 hectares, is under drip irrigation. Irrigated crops have a productivity two to three times higher than the historical average of traditional, rainfed coffee-growing regions (SANTINATO; FERNANDES, 2012).

Among the numerous factors that affect productivity in coffee, mineral nutrition and fertilization should be highlighted. With the increasing use of irrigation and fertigation on crops in Brazil, there has been ongoing concern by producers and technicians with the nutritional status of plants grown under this system.

In Brazil the nutrient sufficiency range is one of the methods used to diagnosis the nutritional status of plants. For a more accurate evaluation, it becomes necessary to establish individual standards for each region and time of year (MARTINEZ et al., 2003).

There are studies which quantify the sufficiency ranges for coffee seedlings (GONÇALVES et al., 2009; GONTIJOetal.,2007),non-irrigatedcropsbeforebecoming established (CLEMENTE et al., 2008) and principally for rainfed crops under production (MALAVOLTA, 1993; MARTINEZ et al., 2003). But for irrigated coffee under production, nutritional recommendations are still based on the behaviour of the rainfed crop. This may compromise development of the plants and lead to a lack or excess of nutrients, due to irrigated coffee having a different pattern of growth and productivity to the non-irrigated crop, as suggested by the results of various studies (CARVALHO et al., 2006;. REZENDE et al., 2010; SILVA; TEODORO; MELO, 2008; SOBREIRA et al., 2011).

For rainfed crops under production, Martinez et al. (2003) recommended for the districts of Guaxupé and São Sebastião do Paraíso, both in the state of Minas Gerais, Brazil (MG), a leaf nitrogen content of 28.30 to $32.00 \mathrm{~g} \mathrm{~kg}^{-1}$ and leaf potassium content of 19.70 to $30.30 \mathrm{~g} \mathrm{~kg}^{-1}$.

Silva et al. (2001) found critical ranges for leaf content of 29.10 to $30.50 \mathrm{~g} \mathrm{~kg}^{-1}$ for $\mathrm{N}$ and 15.70 to $17.60 \mathrm{~g} \mathrm{~kg}^{-1}$ for K in non-irrigated coffee under production.

For a drip-irrigated crop at the production phase in the district of Garanhuns, Pernambuco, Quintela et al. (2011) found that the critical range for leaf nitrogen varied from grain formation to maturity, with respective values of 25.72 to $27.19 \mathrm{~g} \mathrm{~kg}^{-1}$ and 29.24 to $29.60 \mathrm{~g} \mathrm{~kg}^{-1}$.

This study was therefore carried out in order to establish the critical ranges for leaf nitrogen and potassium levels in coffee crops under fertigation at the production phase.

\section{MATERIAL AND METHODS}

The work was carried out in the experimental area of the Sector for Coffee Cultivation of the Department of Agriculture at the Federal University of Lavras (UFLA), MG (21 ${ }^{\circ} 14^{\prime} 06^{\prime \prime} \mathrm{S}$ and $45^{\circ} 00^{\prime} 00^{\prime}$ ' W, altitude $910 \mathrm{~m}$ ), from 2011 to 2012 .

The soil of the experimental area, classified as a dystropheric Red Latosol of a clayey to very clayey texture, was analysed as to the chemical properties of the $0-20 \mathrm{~cm}$ layer, both at the beginning of the experiment (2007) and during the period of evaluation (Table 1).

The crop was planted in April 2007, at a spacing of $2.5 \mathrm{~m}$ between rows and $0.6 \mathrm{~m}$ between plants $(6,666$ plants $\left.\mathrm{ha}^{-1}\right)$. The cultivar used was the Catiguá MG-3 (Catuaí Amarelo IAC 86 x Timor Hybrid UFV 440-10).

Treatments consisted of five levels of fertilization applied by fertigation: $30 \%, 80 \%, 130 \%, 180 \%$ and $230 \%$ of the recommended $\mathrm{N}$ and $\mathrm{K}$ for rainfed coffee plants, divided into four applications during the year, (GUIMARÃES et al., 1999).

A randomised block design was used, with four replications. Each lot consisted of ten plants, with the eight central plants being considered. Double borders were left for each row, so that there would be no interference between treatments. The experiment occupied an area of $900 \mathrm{~m}^{2}$ with 600 plants.

Based on soil analysis (Table 1) and the expected average productivity, the levels of fertilization considered as standard were: $400 \mathrm{~kg} \mathrm{~N} \mathrm{ha}^{-1} \mathrm{yr}^{-1}$ and $75 \mathrm{~kg} \mathrm{~K}_{2} \mathrm{O} \mathrm{ha}^{-1}$, for 2011. The dosages of $\mathrm{N}$ and $\mathrm{K}$ were therefore $120 \mathrm{~kg} \mathrm{~N} \mathrm{ha}^{-1} \mathrm{yr}^{-1}$ and $22.5 \mathrm{~kg} \mathrm{~K}_{2} \mathrm{O} \mathrm{ha}^{-1} ; 320 \mathrm{~kg} \mathrm{~N} \mathrm{ha}^{-1} \mathrm{yr}^{-1}$ and $60 \mathrm{~kg} \mathrm{~K}_{2} \mathrm{O} \mathrm{ha}^{-1}$; $520 \mathrm{~kg} \mathrm{~N} \mathrm{ha}^{-1} \mathrm{yr}^{-1}$ and $97.5 \mathrm{~kg} \mathrm{~K}_{2} \mathrm{O} \mathrm{ha}^{-1} ; 720 \mathrm{~kg} \mathrm{~N} \mathrm{ha}^{-1} \mathrm{yr}^{-1}$ and $135 \mathrm{~kg} \mathrm{~K}_{2} \mathrm{O} \mathrm{ha}^{-1}, 920 \mathrm{~kg} \mathrm{~N} \mathrm{ha}^{-1} \mathrm{yr}^{-1}$ and $172.5 \mathrm{~kg} \mathrm{~K}_{2} \mathrm{O} \mathrm{ha}^{-1}$ for fertilization levels of 30, 80, 130, 180 and 230\% respectively.

For all treatments, fertilization with nitrogen and potassium was carried out four times during the year (November, 2011 to February, 2012). The fertilizers used were urea $(45 \% \mathrm{~N})$ and potassium nitrate $(13 \%$ $\mathrm{N}$ and $44 \% \mathrm{~K}_{2} \mathrm{O}$ ). The phosphorus, in the form of single superphosphate, was applied in one dose $(65 \mathrm{~g}$ per plant) when the crop was planted (April, 2007). The calcium and magnesium came from dolomitic limestone (PRNT $=80 \%$ ) applied in August, 2011. For the total area, $0.84 \mathrm{t} \mathrm{ha}^{-1}$ was applied.

Micronutrients were applied by foliar spraying (January, May and November of 2011) with zinc sulphate, 
Table 1 - Chemical attributes for the 0-20 cm layer of a dystropheric Red Latosol in 2007 and 2011

\begin{tabular}{|c|c|c|}
\hline Atribute & 2007 & 2011 \\
\hline $\mathrm{pH}\left(\mathrm{H}_{2} \mathrm{O}\right)$ & 6.7 & 4.8 \\
\hline Phosphorous (P) - $\mathrm{mg} \mathrm{dm}^{-3}$ & 15.4 & 46.3 \\
\hline Potassium $(\mathrm{K})-\mathrm{mg} \mathrm{dm}^{-3}$ & 137.0 & 205.0 \\
\hline Calcium $\left(\mathrm{Ca}^{2+}\right)-\mathrm{cmol}_{\mathrm{c}} \mathrm{dm}^{-3}$ & 4.4 & 1.80 \\
\hline Magnesium $\left(\mathrm{Mg}^{2+}\right)-\mathrm{cmol}_{\mathrm{c}} \mathrm{dm}^{-3}$ & 1.5 & 0.3 \\
\hline Aluminium $\left(\mathrm{Al}^{3+}\right)-\mathrm{cmol}_{\mathrm{c}} \mathrm{dm}^{-3}$ & 0.0 & 0.4 \\
\hline $\mathrm{H}+\mathrm{Al}\left(\right.$ Extrator SMP) $-\mathrm{cmol}_{\mathrm{c}} \mathrm{dm}^{-3}$ & 2.1 & 6.3 \\
\hline Sum of exchangeable bases (SB) - $\mathrm{cmol}_{\mathrm{c}} \mathrm{dm}^{-3}$ & 6.3 & 2.6 \\
\hline CTC $(\mathrm{t})-\mathrm{cmol}_{\mathrm{c}} \mathrm{dm}^{-3}$ & 6.3 & 3.0 \\
\hline CTC a pH 7.0(T) $-\mathrm{cmol}_{\mathrm{c}} \mathrm{dm}^{-3}$ & 8.3 & 8.9 \\
\hline Base saturation $(\mathrm{V})-\%$ & 74.9 & 30.5 \\
\hline Aluminium saturation $(m)-\%$ & 0 & 8.9 \\
\hline Organic matter (MO) - dag $\mathrm{kg}^{-1}$ & 4.3 & 2.9 \\
\hline Remaining phosphorous (P-rem) - mg L $\mathrm{L}^{-1}$ & 7.7 & 13.8 \\
\hline Zinc $(\mathrm{Zn})-\mathrm{mg} \mathrm{dm}^{-3}$ & 5.1 & 8.5 \\
\hline $\operatorname{Iron}(\mathrm{Fe})-\mathrm{mg} \mathrm{dm}^{-3}$ & 76.7 & 36.3 \\
\hline Manganese $(\mathrm{Mn})-\mathrm{mg} \mathrm{dm}^{-3}$ & 22.5 & 15.1 \\
\hline Copper $(\mathrm{Cu})-\mathrm{mg} \mathrm{dm}^{-3}$ & 3.7 & 4.6 \\
\hline Boron (B) - mg dm ${ }^{-3}$ & 0.2 & 0.2 \\
\hline Sulphur (S) - mg dm ${ }^{-3}$ & 38.2 & - \\
\hline
\end{tabular}

potassium chloride, copper oxychloride and $0.3 \%$ boric acid, according to the recommendation of Guimarães et al. (1999).

Along each crop row, a lateral line of selfcompensating drippers was installed (flow of 3.8 litres per hour), spaced $0.3 \mathrm{~m}$ apart, forming a wet band 0.6 $\mathrm{m}$ in width below each line.

Irrigation management was by tensiometry. Tensiometers were installed at depths of $0.10,0.25,0.40$, $0.60 \mathrm{~m}$, about $0.10 \mathrm{~m}$ away from the base of the orthotropic branch of the plants. Irrigation was carried out whenever the soil water tension at a depth of $0.25 \mathrm{~m}$ reached values close to $20 \mathrm{kPa}$. The values for soil water tension corresponding to field capacity and wilting point, were 10 and $1,500 \mathrm{kPa}$ respectively. The amount of water applied by irrigation, and the rainfall that took place in 2011, were $359.14 \mathrm{~mm}$ and $1,624.12 \mathrm{~mm}$ respectively.

The characteristics being evaluated were: plant height $(\mathrm{cm})$ and stem diameter $(\mathrm{cm})$; leaf nitrogen and potassium levels $\left(\mathrm{g} \mathrm{kg}^{-1}\right)$, and the production of green coffee beans in $60 \mathrm{~kg}$ sacks per hectare in 2012. Measurements for growth, and the determination of leaf nutrient levels were carried out bimonthly in 2011, giving six periods of evaluation: E1 (January/February), E2 (March/April), E3 (May/June), E4 (July/August), E5 (September/October) and E6 (November/December).

Because coffee production is determined based on the growth/development of the crop in the previous year (RENA; MAESTRI, 1986), production data referring to 2012 were used so as to relate them to the levels of fertilization used in 2011.

To evaluate leaf nutrient levels, leaves were collected at the same time growth was measured. From each lot, 32 leaves were sampled from the third or fourth leaf pair, counting from the apex of the plagiotropic branch at middle height on the plant (MARTINEZ et al., 2003).

To determine the critical ranges for leaf $\mathrm{N}$ and $\mathrm{K}$ content, regression models that relate the levels of fertilization to the growth/productivity of the plants were used. After acquiring the quadratic regression, equations were derived for each characteristic within each period, determining the point of maximum growth/productivity. The values for $90 \%$ of maximum performance were then found (REUTER: ROBINSON, 1988). Using the Bhaskara solving formula, ranges were identified for the levels of fertilization which 
resulted in levels of over $90 \%$ of the maximum growth/ productivity of the plants. These levels were substituted in the regression equations that describe the leaf nutrient levels for each sampling period, in order to determine the critical ranges of $\mathrm{N}$ and $\mathrm{K}$ (CLEMENTE et al., 2008).

The data were subjected to variance analysis using the SISVAR software (FERREIRA, 2008). The variables that describe the growth of the coffee plant and leaf nutrient levels were analysed in a scheme of lots split by time, using as sub-lots the level of fertilization, lot and period of evaluation.

\section{RESULTS AND DISCUSSION}

There was significant interaction between period of evaluation and fertilization levels $(\mathrm{P}<0.01)$ for all growth characteristics (Table 2).

The levels of fertilization allowed the adjustment of quadratic models to the characteristic of plant height for all periods of evaluation (Figure 1).

Deriving the equations presented in Figure 1, it was seen that the levels of fertilization that gave maximum plant height varied for each period of evaluation, suggesting that there is a need for applying different amounts of fertilization throughout the year to better meet the needs of the crop.

Obtaining the points of maximum growth for this characteristic was achieved with levels of 194.81, 191.61, $185.04,185.43,192.28$ and $189.59 \%$ of the reference fertilization, for the periods E1, E2, E3, E4, E5 and E6 respectively. These levels are above the recommended level of $100 \%$ standard fertilization proposed by Guimarães et al. (1999). This increase can be attributed mainly to the use of irrigation in the experiment, which promoted higher productivity and therefore a higher demand for nutrients. Similar results of increased fertilization levels in irrigated coffee plants at the production phase were obtained by Costa et al. (2010).

As with plant height, there was adjustment of the quadratic polynomial model to stem diameter in all periods of evaluation (Figure 2).

The maximum growth for this characteristic was reached with fertilization levels of 174.44, 169.83, 173.41, $167.41,164.22$ and $176.10 \%$ for E1, E2, E3, E4, E5 and E6 respectively. Stem diameter is one of the vegetation attributes that most contribute to productivity in the coffee plant (CARVALHO et al., 2010; FREITAS et al., 2007). It is therefore likely that the levels of fertilization which provided maximum stem diameter in the plants for each period are located close to the ideal level of fertilization for coffee productivity.

For the productivity of green coffee in 2012, the quadratic equation presented a suitable adjustment to the data $\left(\mathrm{R}^{2}=0.92\right)$ (Figure 3).

It is evident from this model that productivity reaches a peak of 82.72 bags ha $^{-1}$ when using a fertilization level of $179.91 \%$. After reaching this maximum, productivity decreases in response to the higher levels of fertilization, possibly indicating a nutritional imbalance, especially between potassium and the secondary macronutrients of calcium and magnesium that compete for the same absorption sites (MALAVOLTA et al., 1993; SILVA et al., 2001).

Following the methodology used by Clemente et al. (2008) with the aim of establishing the critical range which would take in all the characteristics under evaluation with a maximum loss of $10 \%$ in development (REUTER; ROBINSON, 1988), it was decided to use the highest value

Table 2 - Summary of variance analysis for the breakdown of fertilization levels within each period, for height, stem diameter, and leaf nitrogen and potassium levels in 2011

\begin{tabular}{lrrrrl}
\hline \multirow{2}{*}{ SV } & \multirow{2}{*}{ DF } & \multicolumn{4}{c}{ Mean square } \\
\cline { 3 - 6 } & & \multicolumn{1}{c}{ Height } & Stem Diameter & N level & K level \\
\hline Levels:E1 & 4 & $195.2647^{* * *}$ & $0.1026^{* * *}$ & $8.0667^{* * *}$ & $4.2423^{\text {ns }}$ \\
Levels:E2 & 4 & $263.7037^{* * *}$ & $0.1056^{* * *}$ & $5.6000^{* *}$ & $4.0073^{\text {ns }}$ \\
Levels:E3 & 4 & $317.8370^{* * *}$ & $0.1059^{* * *}$ & $12.1667^{* * *}$ & $1.1327^{\text {ns }}$ \\
Levels:E4 & 4 & $345.0201^{* * *}$ & $0.0851^{* * *}$ & $5.5667^{* *}$ & $3.5407^{\text {ns }}$ \\
Levels:E5 & 4 & $405.2597^{* * *}$ & $0.0857^{* * *}$ & $23.2333^{* * *}$ & $5.5727^{*}$ \\
Levels:E6 & 4 & $480.7589^{* * *}$ & $0.1071^{* * *}$ & $10.2333^{* * *}$ & $3.9207^{\text {ns }}$ \\
Error & 60 & $1.4502^{* * *}$ & $0.0050^{* * *}$ & 1.6392 & 2.3051 \\
\hline
\end{tabular}

SV - Source of variation; DF - Degree of freedom; ns - not significant, *** significant at $1 \%$,** significant at 5\%, * significant at $10 \%$ probability by F-test 
Figure 1 - Height of fertigated coffee plants subjected to levels of nitrogen and potassium fertilization for six periods of evaluation

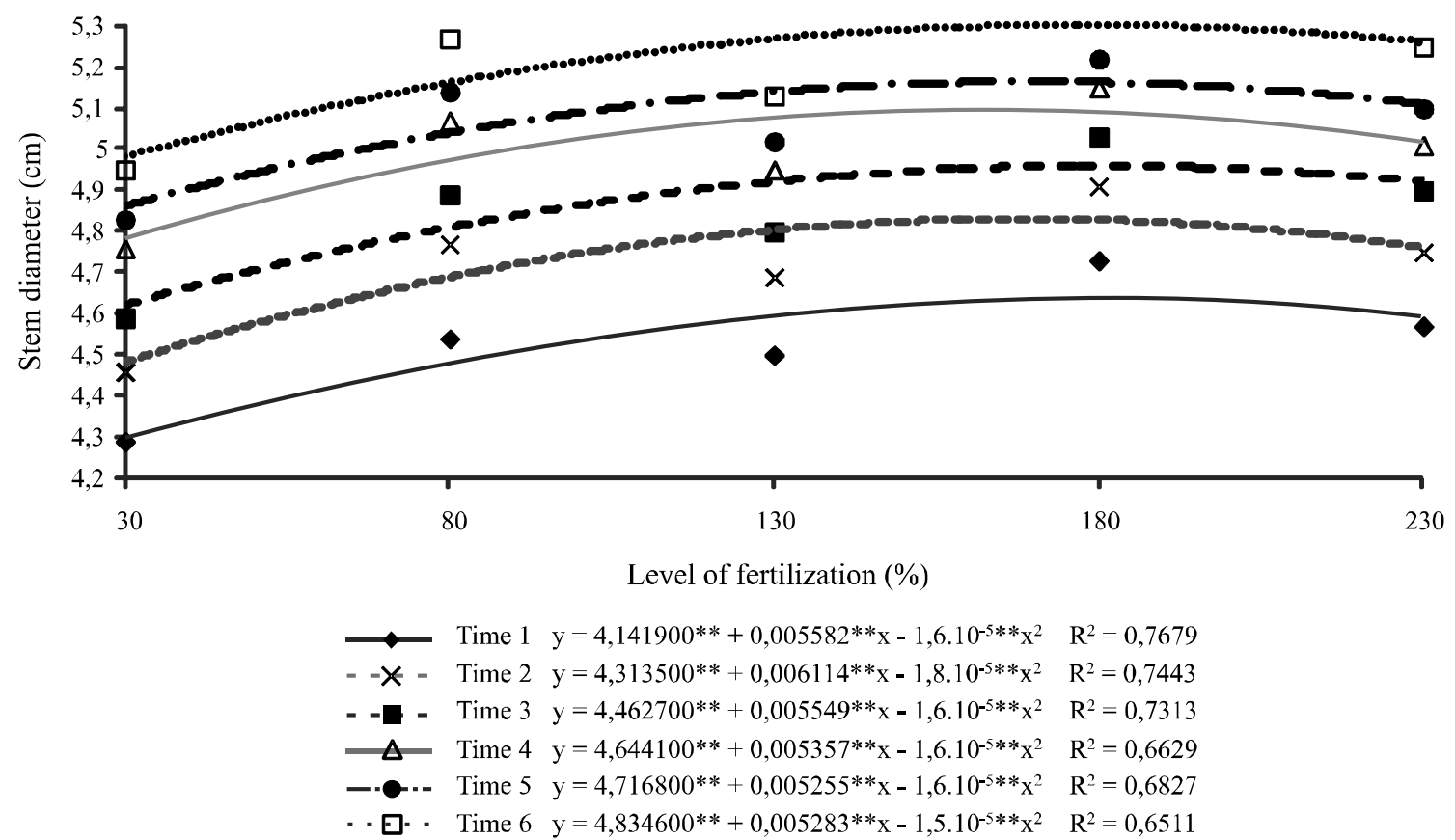

** Significant at de $1 \%$ probability by F-test

Figure 2 - Stem diameter of fertigated coffee plants subjected to levels of nitrogen and potassium fertilization for six periods of evaluation

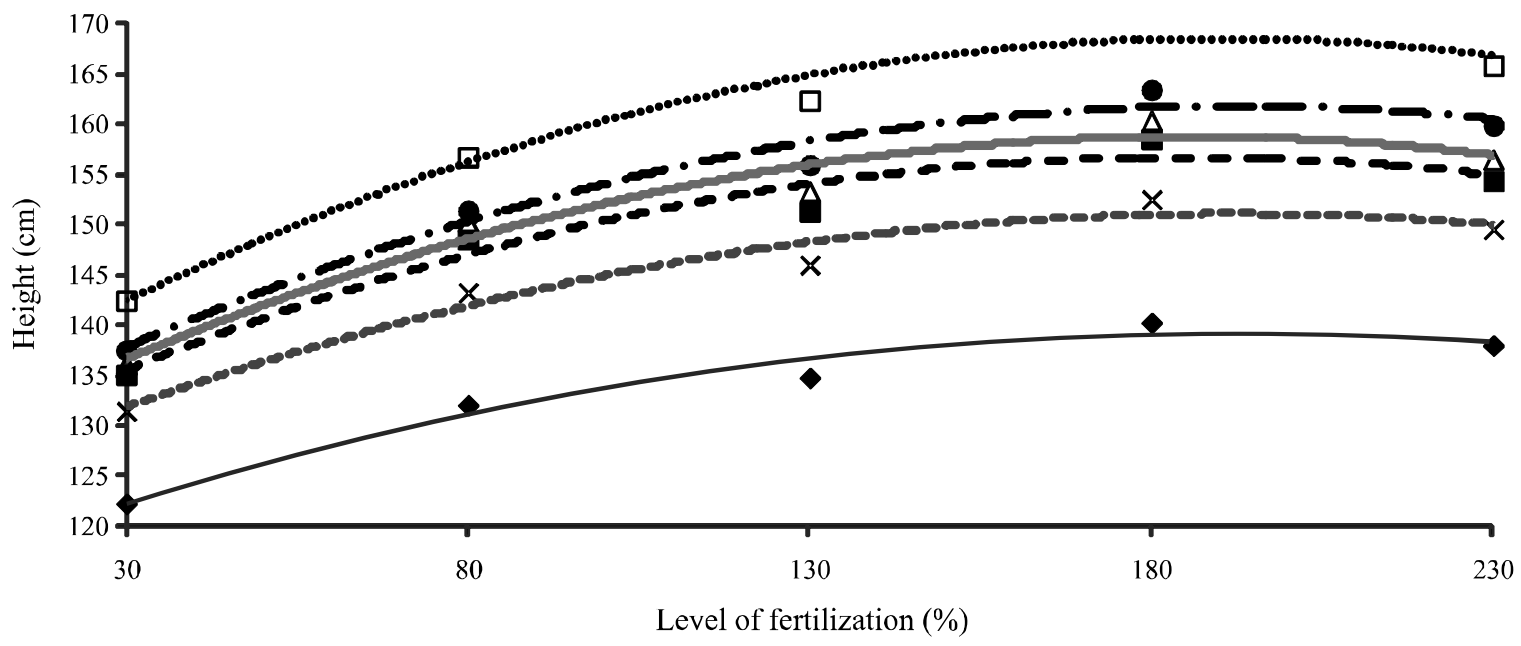

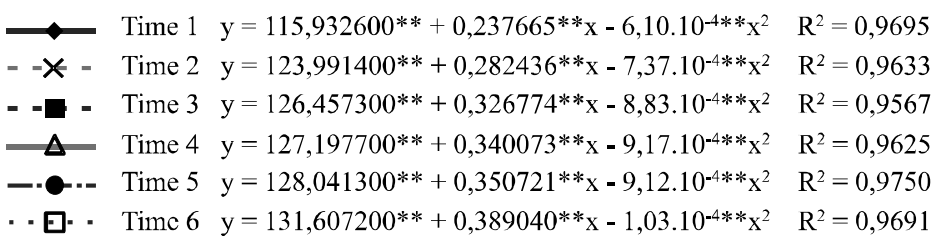

** Significant at $1 \%$ probability by F-test

of the lower limits and the lowest value of the upper limits of the levels of fertilization for each evaluation period found in Table 3. These would later be substituted in the equations relating levels of fertilization to leaf levels. It can be seen in Table 3 that the levels of fertilization suggested for irrigated crops are beyond the proposed recommendations for rainfed 
coffee (GUIMARÃES et al., 1999). As the productivity of irrigated coffee is significantly higher compared to rainfed conditions, this increase in fertilization is consistent with several other results in the literature (COSTA et al.,
2010;. REZENDE et al., 2010; SCALCO et al., 2011). In addition, the nutritional requirements of irrigated coffee are 1.5 to 2.5 times greater compared to non-irrigated coffee (SANTINATO; FERNANDES, 2012).

Figure 3 - Productivity of fertigated coffee plants subjected to levels of nitrogen and potassium fertilization

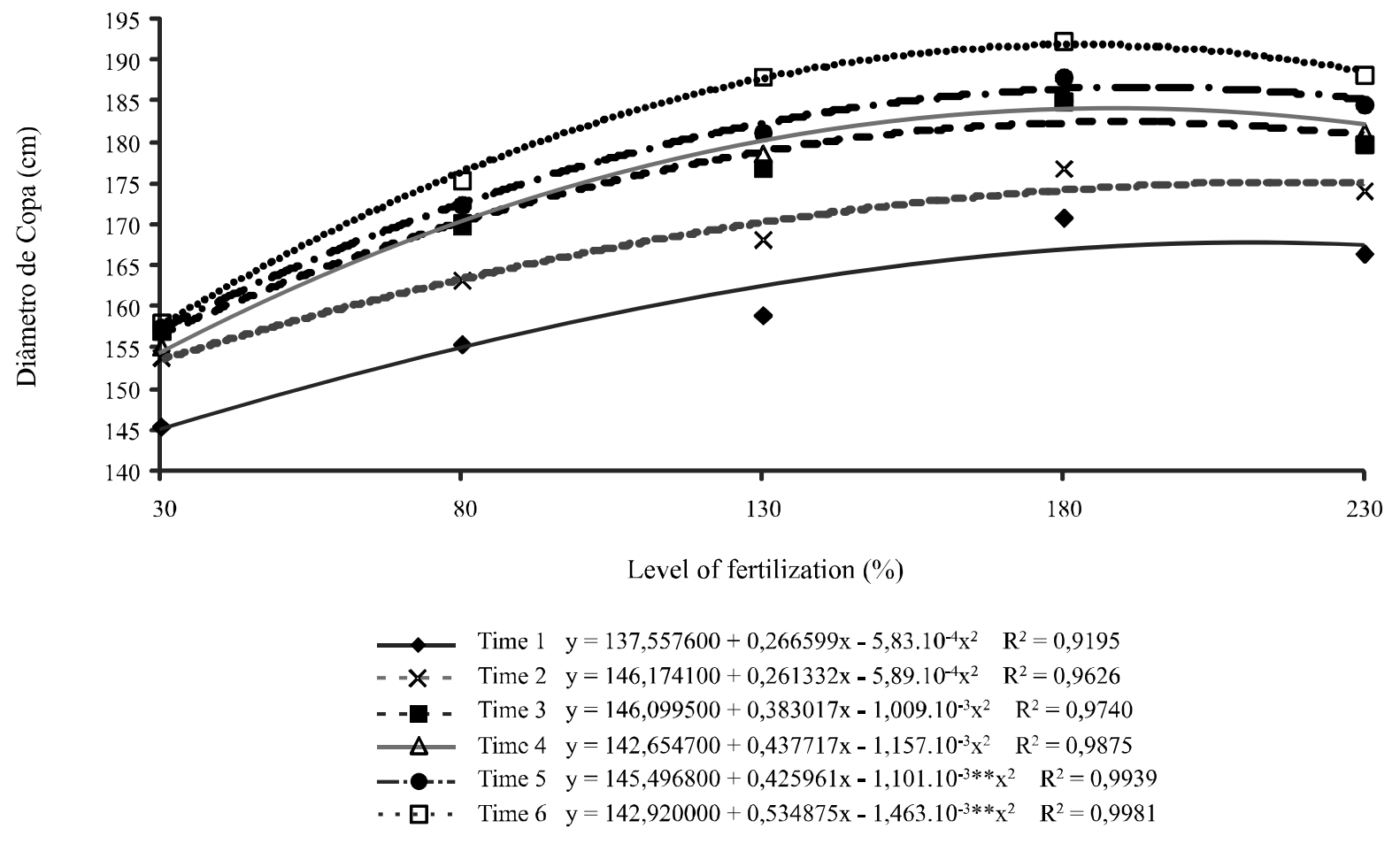

Table 3 - Points for maximum height and stem diameter, 90\% of the maximum and levels of fertilization suitable for fertigated coffee plants subjected to levels of nitrogen and potassium fertilization for six periods of evaluation

\begin{tabular}{|c|c|c|c|c|c|c|}
\hline \multirow[t]{2}{*}{ Caracteristic } & \multirow{2}{*}{$\begin{array}{l}\text { Sampling period } \\
\text { under evaluation }\end{array}$} & \multirow{2}{*}{$\begin{array}{c}\text { Level of } \\
\text { fertlization* }\end{array}$} & \multirow{2}{*}{$\begin{array}{l}\text { Maximum } \\
\text { point (y) }\end{array}$} & \multirow{2}{*}{$\begin{array}{c}90 \% \text { of } \\
\text { maximum }(y)\end{array}$} & \multicolumn{2}{|c|}{$\begin{array}{l}\text { Level of fertilization }(\%) \\
\text { corresponding to } 90 \% \text { of maximum }\end{array}$} \\
\hline & & & & & Lowest & Highest \\
\hline \multirow{6}{*}{ Height $(\mathrm{cm})$} & E1 & 194.81 & 139.08 & 125.17 & 43.80 & 345.82 \\
\hline & E2 & 191.61 & 151.05 & 135.94 & 48.45 & 334.78 \\
\hline & E3 & 185.04 & 156.69 & 141.02 & 51.83 & 318.25 \\
\hline & E4 & 185.43 & 158.73 & 142.86 & 53.87 & 316.98 \\
\hline & E5 & 192.28 & 161.76 & 145.58 & 59.10 & 325.46 \\
\hline & E6 & 189.59 & 168.49 & 151.64 & 61.46 & 317.73 \\
\hline \multirow{6}{*}{ Stem diameter $(\mathrm{cm})$} & E1 & 174.44 & 4.63 & 4.17 & 173.90 & 174.97 \\
\hline & E2 & 169.83 & 4.83 & 4.35 & 169.31 & 170.35 \\
\hline & E3 & 173.41 & 4.94 & 4.45 & 172.85 & 173.96 \\
\hline & E4 & 167.41 & 5.09 & 4.58 & 166.84 & 167.97 \\
\hline & E5 & 164.22 & 5.15 & 4.64 & 163.66 & 164.78 \\
\hline & E6 & 176.10 & 5.30 & 4.77 & 175.51 & 176.69 \\
\hline Productivity (sacks ha-1) & 2012 & 179.91 & 82.72 & 74.45 & 118.69 & 230.00 \\
\hline
\end{tabular}


Another important factor to be considered is that, for the characteristics of growth, the lower and upper limits of fertilization levels (Table 3) are within the ranges for fertilization that made it possible to achieve at least $90 \%$ maximum productivity: $118.69 \%$ and $241.13 \% \mathrm{NK}$ respectively. It is therefore consistent to use growth variables to determine the critical ranges, since these fall within the range established for productivity.

In the evaluation of leaf nitrogen and potassium levels, a significant effect was seen for leaf nitrogen content from the interaction between the levels and periods of fertilization. For potassium, there was a significant effect of fertilization levels on the leaf content of that nutrient for period five only (Table 2).

For the periods when significant effects of fertilization levels on the leaf content of $\mathrm{N}$ and $\mathrm{K}$ were not detected, the critical ranges were determined by interpolation of the data seen for these periods when using the lower and upper limits of those fertilization levels (Table 3) which made it possible to achieve at least $90 \%$ of maximum crop growth.

There was quadratic adjustment of leaf nitrogen content as a function of the fertilization levels for all periods, except May/June (Figure 4). The points of maximum leaf content were 32.59, 33.70, 24.27, 26.64 and $26.51 \mathrm{~g} \mathrm{~kg}^{-1}$ respectively for periods E1, E2, E4, E5 and E6.

In January/February, a sufficiency level of 32.39 to $32.40 \mathrm{~g} \mathrm{~kg}^{-1}$ nitrogen was found. These values are close to the upper limit $\left(31.0 \mathrm{~g} \mathrm{~kg}^{-1}\right)$ of the critical reference range for rainfed crops under production (MALAVOLTA et al., 1993).

The critical range determined for March/ April was 33.60 to $33.61 \mathrm{~g} \mathrm{~kg}^{-1}$, being above the recommendation for non-irrigated crops proposed by Malavolta et al. (1993), namely 26 to $31 \mathrm{~g} \mathrm{~kg}^{-1}$. The nutritional requirement of the coffee plant in the transition stage between grain formation and fruit maturity is relatively high (MATIELLO et al., 2010), especially in fertigated crops, which have greater production in relation to rainfed crops, explaining the higher levels of leaf nitrogen found in this work.

For the third period (May/June), there was increasing linear adjustment of leaf nitrogen content as a function of increased fertilization levels. Thus there is an increase of $0.246 \mathrm{~g} \mathrm{~kg}^{-1}$ in leaf nitrogen content for every $10 \%$ increase in the levels of $\mathrm{N}$ and $\mathrm{K}$.

During this period, sufficiency levels of 27.39 to $27.42 \mathrm{~g} \mathrm{~kg}^{-1}$ were found, being close to the lower limit (28.00 $\mathrm{g} \mathrm{kg}^{-1}$ ) recommended by Malavolta et al. (1993).

Figure 4 - Levels of $\mathrm{N}\left(\mathrm{g} \mathrm{kg}^{-1}\right)$ in leaves of fertigated coffee plants subjected to levels of nitrogen and potassium fertilization for six periods of evaluation

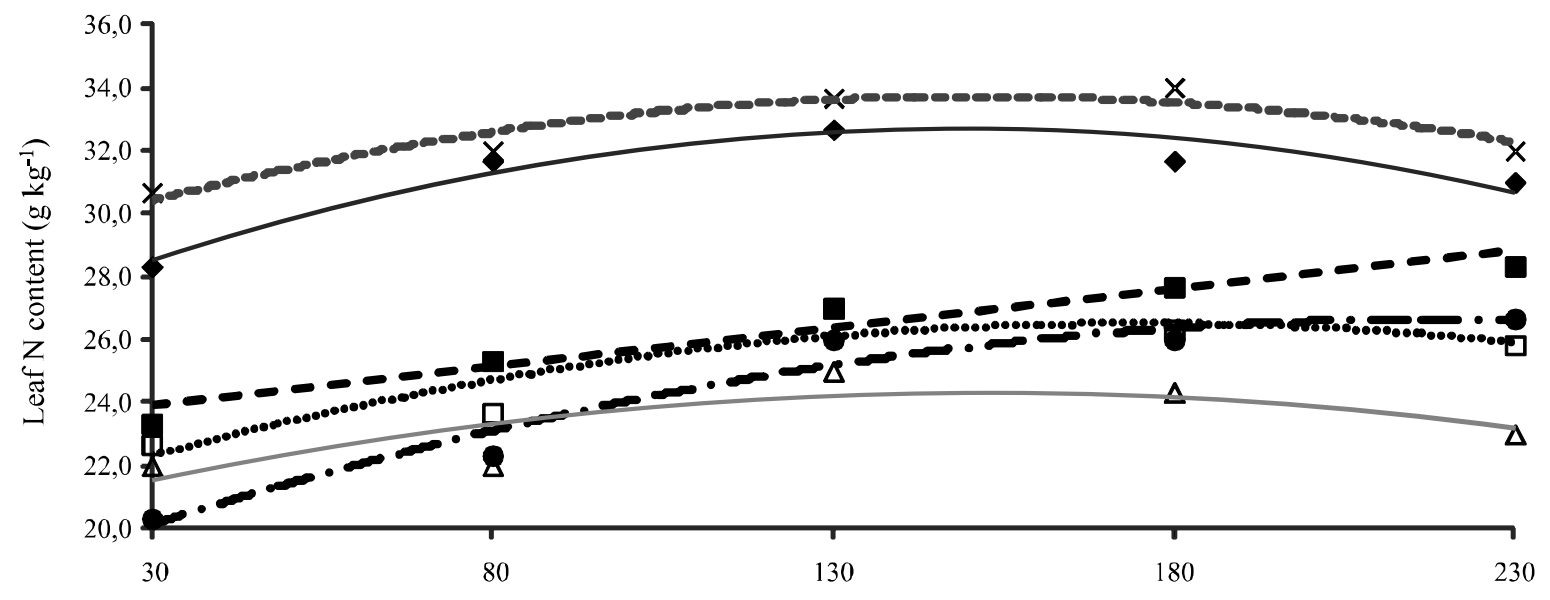

Level of fertilization $(\%)$

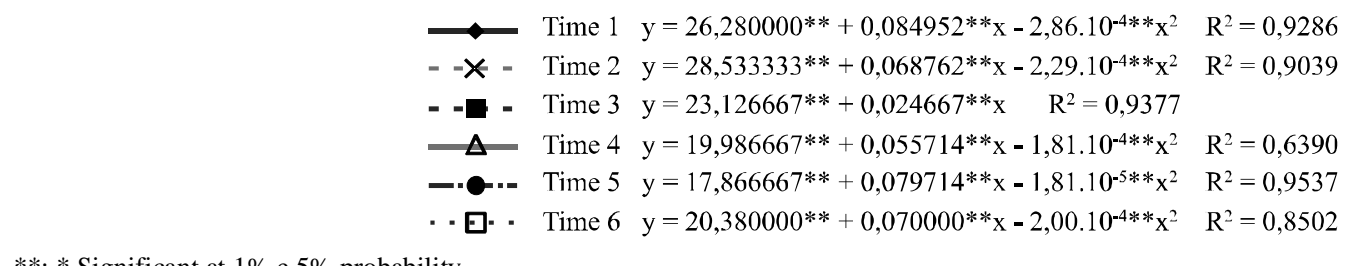

**; * Significant at $1 \%$ e $5 \%$ probability 
Martinez et al. (2003) found values for nitrogen for the whole year of between 28.30 and $32.00 \mathrm{~g} \mathrm{~kg}^{-1}$ for rainfed crops under production.

In July/August, the lowest leaf nitrogen content was $21.50 \mathrm{~g} \mathrm{~kg}^{-1}$ for a fertilization level of $30 \%$, and $23.23 \mathrm{~g} \mathrm{~kg}^{-1}$ for the highest level (230\%). The determined sufficiency levels were from 24.23 to $24.24 \mathrm{~g} \mathrm{~kg}^{-1}$, being below the recommendation (26.00 to $29.00 \mathrm{~g} \mathrm{~kg}^{-1}$ ) made by Malavolta et al. (1993) for a rainfed crop.

For periods E5 (September/October) and E6 (November/December), sufficiency levels were between 26.06 to 26.09 and 26.50 to $26.51 \mathrm{~g} \mathrm{~kg}^{-1}$ respectively. For the same period, however for nonirrigated crops under production, Malavolta et al. (1993) recommend leaf nitrogen levels of between 28.00 and $32.00 \mathrm{~g} \mathrm{~kg}^{-1}$. The use, with irrigated coffee, of critical ranges established for rainfed crops, could cause so-called "luxury consumption" or even toxicity in the irrigated plants, with a decrease in the growth/ production of the crop.

For leaf potassium levels there was significant adjustment $\left(\mathrm{R}^{2}=0.80\right)$ of the quadratic model to the leaf content of this nutrient in period E5 only (September/ November) (Figure 5).

The highest levels for leaf potassium content were $18.51 \mathrm{~g} \mathrm{~kg}^{-1}$ for a fertilization level of $30 \%$, and $19.08 \mathrm{~g} \mathrm{~kg}^{-1}$ for $230 \%$. The minimum point for leaf content was $16.22 \mathrm{~g} \mathrm{~kg}^{-1}$. The difference between the highest and lowest levels was $0.57 \mathrm{~g} \mathrm{~kg}^{-1}$.

The sufficiency levels determined for September/October were 16.61 to $16.64 \mathrm{~g} \mathrm{~kg}^{-1}$, which are values close to those found by Silva et al. (2001) who suggested leaf potassium levels for coffee crops under production of between 15.70 and $17.60 \mathrm{~g} \mathrm{~kg}^{-1}$ for the whole year. However, these values are lower than those recommended by Malavolta et al. (1993) for non-irrigated coffee plants under production for that period (22.00 to $25.00 \mathrm{~g} \mathrm{~kg}^{-1}$ ). Thus, for the same time of year, irrigated crops have less need for potassium than rainfed crops, which makes it possible to infer that for future studies on the division of fertilization of irrigated crops into different amounts of potassium per application, a smaller amount should be adopted for the same period.

For periods E1, E2, E3, E4 and E6, adjusted leaf potassium levels are respectively: 20.08 to $20.14,17.89$ to $17.91,15.93$ to $15.96,15.29$ to 15.35 and 20.58 to $20.64 \mathrm{~g} \mathrm{~kg}^{-1}$. These values are lower than the critical ranges for rainfed crops under production determined by Malavolta et al. (1993).

The critical ranges presented for nitrogen and potassium in the present study are consistent with the values suggested by Martinez et al. (2003) and Silva et al. (2001). The differences found in leaf content for some periods of evaluation are mainly due to the use of irrigation and fertigation in this experiment.

Figure 5 - Levels of $\mathrm{K}_{\left(\mathrm{g} \mathrm{kg}^{-1}\right)}$ in leaves of fertigated coffee plants subjected to levels of nitrogen and potassium fertilization for six periods of evaluation

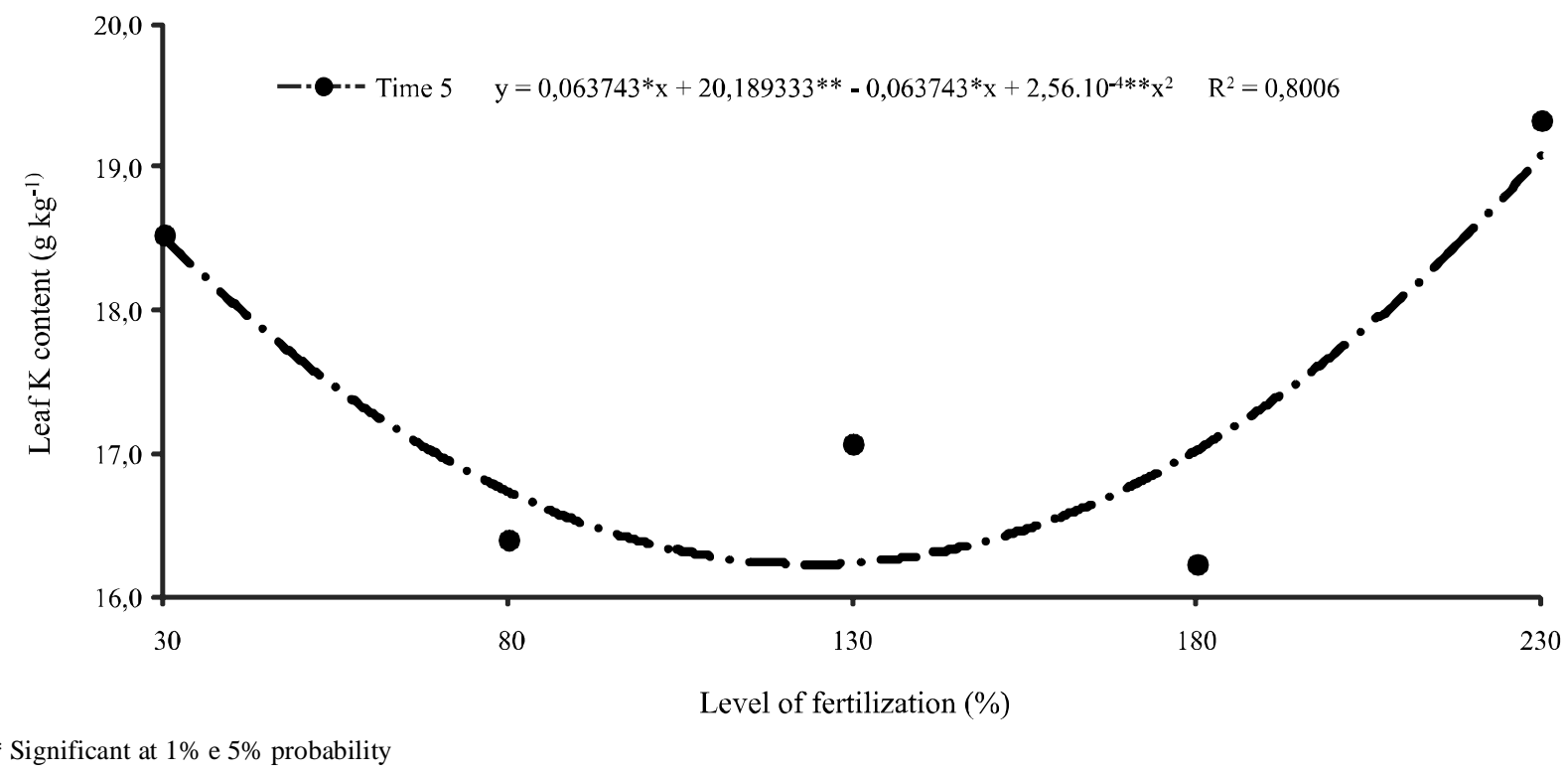




\section{CONCLUSIONS}

Sufficiency levels for nitrogen and potassium in fertigated coffee crops under production are:

1. Nitrogen $\left(\mathrm{g} \mathrm{kg}^{-1}\right): 32.39$ to 32.40 in January/February; 33.60 to 33.61 in March/April; 27.39 to 27.42 in May/June; 24.23 to 24.24 in July/August; 26.06 to 26.09 in September/ October and 26.50 to 26.51 in November/December;

2. Potassium $\left(\mathrm{g} \mathrm{kg}^{-1}\right)$ : 20.08 to 20.14 in January/February; 17.89 to 17.91 in March/April; 15.93 to 15.96 in May/June; 15.29 to 15.35 , in July/August; 16.61 to 16.64 in September/October and 20.58 to 20.64 in November/December.

\section{ACKNOWLEDGEMENTS}

The authors wish to thank $\mathrm{CNPq}$ for granting a Junior Postdoctoral scholarship to the first author of the work. Thanks are also due to the Brazilian Coffee Research Consortium and the Foundation for Research Support of the State of Minas Gerais (FAPEMIG) for their financial support.

\section{REFERENCES}

CARVAlHO, A. M. et al. Correlação entre crescimento e produtividade de cultivares de café em diferentes regiões de Minas Gerais, Brasil. Pesquisa Agropecuária Brasileira, v. 45, n. 3, p. 269-275, 2010.

CARVALHO, C. H. M. et al. Evolução do crescimento do cafeeiro (Coffea arabica L.) irrigado e não irrigado em duas densidades de plantio. Ciência e Agrotecnologia, v. 30, n. 2, p. 243-250, 2006 .

CLEMENTE, F. M. V. T. et al. Faixas críticas de teores foliares de macronutrientes no cafeeiro em pós-plantio - Primeiro Ano. Coffee Science, v. 3, n. 1, p. 47-57, 2008.

COSTA, A. R. et al. Número de ramos plagiotrópicos e produtividade de duas cultivares de cafeeiro utilizando irrigação por gotejamento. Revista Ciência Agronômica, v. 41, n. 4, p. 571-581, 2010.

FERREIRA, D. F. SISVAR: um programa para análises e ensino de estatística. Revista Symposium, v. 6, n. 1, p. 36-41, 2008

FREITAS, Z. M. T. S. et al. Avaliação de caracteres quantitativos relacionados com o crescimento vegetativo entre cultivares de café arábica de porte baixo. Bragantia, v. 66, n. 2 , p. $267-275,2007$.
GONÇALVES, S. M. et al. Faixas críticas de teores foliares de micronutrientes em mudas de cafeeiro (Coffea arabica L.) produzidas em tubetes. Revista Ciência e Agrotecnologia, v. 33, n. 3, p. 743-752, 2009.

GONTIJO, R. A. N. et al. Faixas críticas de teores foliares de micronutrientes em mudas de cafeeiro (Coffea arabica L.). Coffee Science, v. 2, n. 2, p. 135-141, 2007.

GUIMARÃES, P. T. G. et al. Cafeeiro. In: RIBEIRO, A. C.; GUIMARÃES, P. T. G.; AlVAREZ, V. V. H. (Ed.). Recomendação para o uso de corretivos e fertilizantes em Minas Gerais: $5^{\text {a }}$ aproximação. Viçosa: Comissão de Fertilidade do Solo do Estado de Minas Gerais, 1999. p. 289- 302.

MALAVOLTA, E. et al. Seja o doutor do seu cafezal. Piracicaba: Potafos, 1993. 36 p. (Arquivo do Agrônomo, 3)

MARTINEZ, H. E. P. et al. Faixas críticas de concentrações de nutrientes e avaliação do estado nutricional de cafeeiros em quatro regiões em Minas Gerais. Pesquisa Agropecuária Brasileira, v. 38, n. 6, p. 703-713, 2003.

MATIELLO, J. B. et al. Cultura de café no Brasil: manual de recomendações. Rio de Janeiro: MAPA/PROCAFÉ, 2010. 542 p.

QUINTELA, M. P. et al. Parâmetros produtivos e nutricionais do cafeeiro submetido adubação nitrogenada na região de Garanhuns. Revista Caatinga, v. 24, n. 4, p. 74-79, 2011.

RENA, A. B.; MAESTRI, M. Fisiologia do cafeeiro. In: RENA, A. B. et al. (Ed.). Cultura do cafeeiro: fatores que afetam a produtividade. Piracicaba: Associação Brasileira para Pesquisa da Potassa e do Fosfato, 1986. p. 13-85.

REUTER, D. J.; ROBINSON, J. B. Plant analysis: an interpretation manual. Melbourne: Inkata, 1988. 218 p.

REZENDE, F. C. et al. Cafeeiro recepado e irrigado em diferentes épocas: produtividade e qualidade. Coffee Science, v. 5, n. 3, p. 229-236, 2010.

SANTINATO, R.; FERNANDES, A. L. T. Cultivo do cafeeiro irrigado por gotejamento. 2. ed. Uberaba, 2012. 388 p.

SCALCO, M. S. et al. Cultivo irrigado e não irrigado do cafeeiro em plantio superadensado. Coffee Science, v. 6, n. 3, p. 193-202, 2011.

SILVA, C. A. da; TEODORO, R. E. F.; MELO, B. de. Produtividade e rendimento do cafeeiro submetido a lâminas de irrigação. Pesquisa Agropecuária Brasileira, v. 43, n. 3, p. 387 394, 2008.

SILVA, E. B. et al. Adubação potássica do cafeeiro: produção, faixas críticas de nutrientes no solo e nas folhas. Ciência e Agrotecnologia, v. 25, n. 4, p. 801-811, 2001.

SOBREIRA, F. M. et al. Adubação nitrogenada e potássica de cafeeiro fertirrigado na fase de formação, em plantio adensado. Pesquisa Agropecuária Brasileira, v. 46, n. 1, p. 9-16, 2011. 